\title{
Notes
}

\section{Executory Labor Contracts and Municipal Bankruptcy}

New York City's fiscal crisis ${ }^{1}$ and Congress's subsequent revision of Chapter IX of the Bankruptcy Act ${ }^{2}$ have raised questions about the status of labor contracts in a municipal bankruptcy. Under what conditions, if any, can municipal employee contracts be rejected in bankruptcy? After rejecting a contract, can a city unilaterally institute revised terms of employment, to stay in effect until a new contract is signed? This Note examines the likely impact of the new provisions concerning municipal employee contracts and analyzes several contradictions between the understanding of the House and the Senate as to the working of the new Chapter IX.

1. New York City nearly defaulted on the repayment of its bonded debt in October, 1975. For discussion of New York's financial crisis, see N.Y. Times, Aug. 30, 1975, $\$ 4$, at 1, col. 3; id., Oct. 18, 1975, $\$ 1$, at 1, col. 8; Bus. WEEK, Sept. 1, 1975, at 51, 53; H.R. ReP. No. 94-632, 94th Cong., 1st Sess., pt. I, at 2-9, 49-53 (1975).

2. Repealed Chapter IX, governing compositions of municipal indebtedness, is presently codified at 11 U.S.C. $\$ \$ 401-403$ (1970). It was superseded this year by the Act of April 8, 1976, Pub. L. No. 94-260, [1976] U.S. Code Cong. \& Ad. News (90 Stat. 315-25) (to be codified at 11 U.S.C. $\$ \$ 401-418$ ). Hereinafter, references to the revised version will be to the section number of the new Act only. Before the latest amendments, the capacity of Chapter IX to relieve the financial difficulties of large cities had been questioned. E.g., Note, Reform of Creditor Participation Procedures in Municipal Bankruptcy, 85 YALE L.J. 423 (1976). (Municipal corporations are denied relief under other chapters of the Bankruptcy Act. 11 U.S.C. $\$ \$ 22(a), 506(3), 506(5), 706(3)(1970)$.)

Comprehensive revision of the entire Bankruptcy Act, including Chapter IX, has been under active consideration since January, 1975. See, e.g., H.R. 31, 94th Cong., Ist Sess. (1975); S. 236, 94th Cong., 1st Sess. (1975). New York City's fiscal crisis caused Congress to accelerate its consideration of the municipal bankruptcy proposals, and several bills dcaling exclusively with municipal bankruptcy were introduced. The House bill, H.R. 10624, 94th Cong., 1st Sess. (1975), was reported in H.R. REP. No. 94-686, 94th Cong., 1st Sess. (1975) [hereinafter cited as House RePorT]. The Senate bill, S. 2597, 94th Cong., 1st Sess. (1975), substantially similar to the House bill, was reported in S. REP. No. 94458, 94th Cong., 1st Sess. (1975) [hereinafter cited as SENATE REPORT]. An amended version of H.R. 10624 was reported by the House-Senate Conference in H.R. REP. No. 94-938, 94th Cong., 2d Sess. (1976) [hereinafter cited as CoNFERENCE REPORT]. It was agreed to by both Houses of Congress on Mar. 25, 1976, 122 CoNG. REc. H2384, S4378 (daily ed., Mar. 25, 1976), and was signed into law in April.

Under revised Chapter IX, a municipality files a petition in federal court alleging insolvency. $\$ 84$. Filing of a petition acts as an automatic stay of all suits against the city, $\$ 85(\mathrm{e})$, affording time for orderly negotiation of a plan to adjust the city's debts, $\$ 91$. The court classifies the city's creditors according to the nature of their claims (e.g., secured or unsecured). $\$ 88(\mathrm{~b})$. This classification scheme determines the order in which creclitors are paid under the plan. Each class of creditors must approve the plan 


\section{Procedures for Rejection of Labor Contracts in Municipal Bankruptcy}

Collective bargaining contracts are executory insofar as the obligations of both parties remain substantially unperformed. ${ }^{3}$ Bankrupts in the private sector long have been empowered to reject executory contracts that are onerous or burdensome to the estate, ${ }^{4}$ including in some circumstances collective bargaining agreements. ${ }^{5}$ The new legislation makes this power plainly available to municipal debtors for the first time. ${ }^{6}$ Although the statute does not refer to municipal employee contracts, the accompanying House and Senate Reports agree that these contracts are subject to rejection. ${ }^{7}$

by a vote of two-thirds in amount and a majority in number of claims voted, unless the court finds that the plan compensates the class adequately. $\$ 92$. The court will confirm a plan that is fair and equitable, $\$ 94(b)$, discharging the city from its debts, $\$ 95(b)$. For a general discussion of the provisions of the new municipal bankruptcy legislation, see House REPORT, supra, at 6-14.

3. "Executory contract" is not defined in the old Bankruptcy Act nor in the Act as amended, but the SENATE REPORT, supra note 2, at 15, construes the term broadly: "The Committee contemplates that all continuing obligations of the petitioner will be considered executory contracts, including collective bargaining agreements." Accord, HousE REPORT, supra note 2, at 57 (Supplemental Views). Countryman, Executory Contracts in Bankruptcy: Part I, 57 MinN. L. REv. 439, 460 (1973), defines the term as a contract under which the obligations of both parties "are so far unperformed that the failure of either to complete performance would constitute a material breach excusing the performance of the other."

As of the date of filing of a Chapter IX petition, a municipal employee contract is executory over its remaining life. The contract is not exccutory with respect to claims for past wages, since employees will have fully discharged the contractual duties which created the claims. See Countryman, Executory Contracts in Bankruptcy, Part II, 58 Minn. L. Rev. 479, 480 (1974) [hereinafter cited as Countryman, Part II]. A municipality's assumption or rejection of a labor contract thus will have no effect on claims for prefiling wages. Those claims will be adjusted in accordance with the newly established wage priority. (The new legislation establishes three types of "priority" expenses, $\$ 89$, which must be paid in full before any distributions to creditors are made under the plan. The first, or highest, priority is for administrative expenses-costs incurred in running the city after the filing date as well as costs of the bankruptcy proceeding itself, The second priority covers services and materials provided to the city within three months before filing, including workers' wages and fringe benefits. The third priority is for debts to the federal government.)

4. 11 U.S.C. $\$ 110(\mathrm{~b})(1970)$ (straight bankruptcy); $i d . \$ 205(\mathrm{~b})$ (railroad xcorganiza. tion); id. $\$ \S 516(1), 616(4)$ (Chap. X reorganization); id. $\$ \S 713(1), 757(2)$ (Chap. XI arrangement).

5. See Brotherhood of Ry. Employees r. REA Express, Inc., 523 F.2d 161, 169 (2d Cir.), cert. denied, 423 U.S. 1017 (1975) and 423 U.S. 1073 (1976); C. MoRRIS, The Develop. ing Labor Law 817-18 (1971); Countryman, Part 11 , supra note 3 , at $492-98$.

6. $\$ \$ 82(\mathrm{~b})(1), 91$. The House REPORT, supra note 2 , at 8 , observes that the power to reject executory contracts "had not previously been granted under Chapter IX." Section 83(a) of repealed Chapter IX, 11 U.S.C. $\$ 403(a)$ (1970), may have provided a possible vehicle for rejection: a city's plan of composition could contain "such other provisions and agreements not inconsistent with [Chapter $I X]$ as the parties may desire." But no case has been reported in which a municipal debtor used this provision to reject an exccutory contract through its plan.

7. House RePort, supra note 2, at 8, 17; SeNate Reyort, supra note 2, at 15. The Act and accompanying reports do not define the power of rejection. Where legislative 
The statute offers two procedures for rejecting executory contracts. The first procedure ( $\$ 91$ rejection $)^{s}$ uses as a mechanism the plan of adjustment approved at the end of any successful Chapter IX proceeding. A city must submit a plan for the adjustment of its debts at the time it files a Chapter IX petition, or at some time after filing, as the court directs. ${ }^{a}$ This plan may include provisions modifying the rights of creditors generally, and "such other provisions and agreements not inconsistent with [Chapter IX] as the parties may desire, including provisions for the rejection of any executory contract or unexpired lease."10 The "parties," in the case of a municipal employee contract, include at least the union and the city; ${ }^{11}$ the plan of adjustment thus cannot provide for rejection of a labor contract unless the union "desires" it." In addition, the court, after a hearing, must approve the

history is thus silent, this Note will draw upon the standards evolved in Chapters $\mathrm{X}$ and XI. See House RePort, stura at 17 ("The abundant case law surrounding [rejection of executory contracts] is meant to be incorporated into Chapter IX.")

Under revised Chapter IX, a municipality desiring to reject a collective bargaining agreement must reject the entire contract and do so explicitly. The city cannot retain the adiantagcous features of a contract and cast off the rest. $C f$. 6 Collier oN BANKRuptcy if 3.24[1] (14th ed. 1972) [hereinafter cited as Collier]; 8 id. If 3.15[7] (14th ed. 1970) (discussing Chaps. X \& XI).

Although the new legislation contains no cxpress provision for assumption of executory contracts, the power to assume must be implicd. Otherwise, a power of rejection would be meaningless. Cf. 6 id. $\$ 3.23$ [5] (Chap. X). Assumption, like rejection, must be of the entire contract. Cf. 6 id. I 3.24[2] (Chap. X); 8 id. i 3.15[6] (Chap. XI). Assumption must be explicit and must have judicial sanction before becoming effective. $C f$. id. If 3.23[5] (Chap. X); In ic Schenectady Ry., 93 F. Supp. 67 (N.D.N.Y. 1950) (tacit acceptance of labor contract does not constitute assumption). Bul see In re Public Ledger, Inc., 161 F.2d 762 (3d Cir. 1947), rev'g 63 F. Supp. 1008 (E.D. Pa. 1945) (knowing conformity to terms of labor contract constitutes assumption, cren without judicial approval). In the absence of extraordinary circumstances, assumption of a contract would bar later rejection. Cf. 6 Collicr, supra of $3.24[2]$ (Chap. X); 9 id. If 8.27 (14th cd. 1975) (Chap. XI). Expenses under an assumed labor contract would be first priority expenses of administration. Cf. Countryman, Part II, supra note 3, at $494-96$ (discussing Chaps. X \& XI).

8. $\$ 91$.

9. $\$ 90(\mathrm{a})$.

10. $\$ 91$.

11. The term "parties" does not seem to be confined to those signatory to the executory contract. The language of 11 U.S.C. $\$ 403(1970)$, predecessor to $\$ 91$, used the term "partics" without mentioning either executory contracts or leases. See note 6 supra. In addition, the new law elșewhere uses the more explicit term "parties to such contracts [or] leases" to denote the signatories, $\$ 82(b)(1)$, and uses the term "parties in interest" to indicate any parties affected by the plan, $\$ \$ 82(\mathrm{~b})(\mathrm{l}), 85(\mathrm{a}), 88,90(\mathrm{~b})$. Parties other than the union may be interested in preventing rejection of a labor contract. For instance, unsecured creditors may believe that the union's damage claim arising from rejection, see pp. 96061 infra, will so dilute their share of the distributed funds as to disadrantage them more than would continuation of the old contract.

12. In allowing the other contracting party to block $\$ 91$ rejection of an executory contract, revised Chapter IX differs significantly from Chapters $X$ and $X I$. Under Chapter $\mathrm{X}$, a debtor may include in the plan provision for rejection of any executory contract "except contracts in the public authority." 11 U.S.C. $\$ 616(4)$ (1970). Under Chapter XI, "the debtor's right to provide for rejection in his plan is absolute, subject to confirmation of the plan." 9 CoLLIER, supra note $7, \mathbb{1} 8.07$, at 181 . 
entire plan as "fair and equitable."13 But it is primarily the requirement of union consent which makes this form of rejection impractical. ${ }^{14}$

The second procedure ( $\$ 82(\mathrm{~b})$ rejection) ${ }^{\mathbf{1 5}}$ allows rejection despite union opposition and so will be more attractive to most cities wishing to reject labor contracts. The city may seek judicial approval for rejection at any time after filing its petition. The court must hold a hearing concerning rejection, giving notice to the affected municipal union and to "such other parties in interest as the court may designate."10 If requisite standards for rejection are met, ${ }^{1 \tau}$ the court may permit rejection even over union opposition since there is no provision requiring the city to obtain consent from other parties. Apparently rejection is immediately effective and remains so whether or not the plan is ultimately confirmed. ${ }^{18}$

Rejection of a collective bargaining agreement by either method constitutes a breach of contract as of the date the Chapter IX petition was filed, giving rise to a union claim for the full amount of damages

13. $\$ 94(b)(1)$. The union has the right to intervene in this general hearing, for rejection gives rise to a damage claim for breach of contract, see pp. 960-61 infra, making the union a "creditor" within the meaning of $\$ 93$. The rejection does not become effective until the confirmation of the plan, cf. 6 Collier, supra note 7, [3.24[1] (Chap. X); 8 id. T 3.15[9] (Chap. XI), and thus the union's damage claim comes into existence only upon confirmation. Yet such prospective damage has been deemed sufficient in Chapters $\mathbf{X}$ and XI to render a party to a rejected contract a "creditor," entitling him to voice objections to and vote on the plan along with other creditors. 11 U.S.C. $\$ \$ 602,753(1970)$; 6 Collier, supra $\{$ 3.23[2], at 565; id. I 3.2, at 583 n.62, 584 n.64 (Chap. X); 9 id. If 8.05, at 1071 (Chap. XI).

However, the standard of "fairness and equity" by which the plan as a whole is judged in the general hearing, $\$ 94(\mathrm{~b})(\mathrm{I})$, may be less exacting in regard to rejection than is the balancing of equitics encompassed in a hearing devoted solely to rejection, such as the Jearing held under $\$ 82(\mathrm{~b})$, see pp. 960, 961-65 infra. The "fair and equitable" standard embodies the absolute priority rule, requiring full compensation of senior creditors before any payout is made to junior creditors. House REPORT, supra note 2, at 32 . Still, it also requires "that the plan embody a fair and equitable bargain, openly arrived at and devoid of overreaching." Id. at 33.

14. A union might consent to rejection through the plan knowing that under the amended Act the court could authorize unilateral rejection by the city. See discussion below. If the city provided for rejection in the plan, it would presumably incorporate by reference its new agreement with the union. See generally House RePorr, supra note 2, at 12. Upon confirmation of the plan, the old contract would lapse and the new agrecment automatically take effect.

15. $\$ 82(\mathrm{~b})(\mathrm{l})$.

16. Id. Who the other parties in interest may be is not specified by the Act or by the accompanying reports. It seems likely that the city's other creditors or their representatives are those intended. Cf. 6 Collies, supra note 7, I 3.25 (Chap. X); 8 idl. 53.16 (Chap. XI).

17. See pp. 961-65 infra. The decision to allow rejection rests in the discretion of the court. "The court may' . . permit the petitioner to reject executory contracts . . . ." $\$$ 82(b) (emphasis added). Cf. 6 Collier, supra note 7, f 3.23[4] (Chap. X); 8 id. If 3.15[13] (Chap. XI).

18. Cf. 6 Collier, supra note 7, if 3.24[1] (Chap. X); 8 id. If 3.15[9] (Chap. XI). 
against the city. ${ }^{19}$ However, the claim for damages does not rise to the status of a priority administrative expense and must be dealt with in the plan. ${ }^{.0}$ The union participates in the plan merely as an unsecured general creditor. ${ }^{21}$

\section{Limitations on the Power to Reject Municipal Labor Contracts}

\section{A. The Standards for Rejection}

The new statute is silent regarding the standards which should guide the court in considering the rejection of executory contracts. The House Report suggests that standards for rejection of labor contracts are meant to be considerably more stringent than for rejection of other executory contracts.22 There are no cases of rejection under the old Chapter IX to provide guidance; ${ }^{23}$ accordingly the House Report turns to judicial standards evolved under other chapters of the Bankruptcy Act. Chapter X and XI courts generally have permitted rejection of nonlabor executory contracts upon a showing that the contract is burdensome and that rejection will aid the petitioner's reorganization. ${ }^{24}$ A debtor under those chapters can gain judicial approval for rejection merely by demonstrating that rejection would be financially beneficial. ${ }^{25}$ But with respect to labor contracts, as the Report notes, "the courts have taken a slightly different position on the grounds for

19. The Act puts no ceiling on the union's claim for damages resulting from the breach. See Hovse Report, supra note 2, at 27. Cf. 9 Collier, supra note 7, If 7.15[6.2] (Chap. XI). Compare the explicit limit, of one year's rent plus any unpaid back rent, set by the Act on a landlord's recovery for breach of an unexpired lease. $\$ 88(c)$. The union's unliquidated claim for damages would be filed at a time set by the court. $\$ 88(a)$. The likely measure of the union's damages is the difference in benefits between the old and new contracts (or between the old contract and the interim terms established pending rencgotiation of a new contract), from the date rejection becomes effective until the expiration date of the old contract.

20. $\$ \$ 8(c)$; Housc Rerokr, supra note 2, at 27. For the status of administration cxpenses, sce note 3 supra.

21. Since all sccured creditors must be paid in full before unsecured creditors recorer anything, $\$ 94(\mathrm{~b})(\mathrm{l})$; House RePORT, supra note 2 , at 32 , it is unlikely that the union would recover the full amount of its damage claim under the plan.

22. Housc Report, supra note 2, at 17. The ScNate Report, supra note 2, is mute on this isstue, as it is on most aspects of the rejection of executory contracts. The Confercice Rrport, supra note 2, and the subsequent Senate floor debate, p. 968 \& note 64 infra, also are silent.

23. See note 6 supra.

24. See House Report, supra note 2, at 17.

25. See 6 Coln.1ER, supra note 7, If 3.23[4] (Chap. X); 8 id. I 3.15[8] (Chap. XI). With respect to executory contracts in general, courts rarely withhold approval for rejection; the debtor's showing of oncrousness necd only be perfunctory. 
rejection, requiring a showing of a greater burden on the petitioner." 23 This standard, according to the House, is incorporated into revised Chapter IX.27

The contours of the judicial standard are derived by the House Report from three Chapter XI decisions. In the earliest, In re Overseas National Airways, Inc., ${ }^{28}$ a federal district court noted that rejection of a labor contract might deprive workers of intangible benefits such as seniority, welfare, and pension rights and should be permitted "only after thorough scrutiny, and a careful balancing of the equities on both sides." ${ }^{29}$ In Shopmen's Local Union No. 455 v. Kevin Steel Products, Inc., ${ }^{30}$ the Second Circuit stated that the "decision to allow rejection should not be based solely on whether it will improve the financial status of the debtor" and that a bankruptcy court must "move cautiously" in allowing such rejection; it specifically endorsed the balancing test of Overseas National Airways. ${ }^{31}$ This endorsement was repeated one month later in Brolherhood of Railway Employees $v$. REA Express, Inc., ${ }^{32}$ which follows closely the reasoning and conclusions of Kevin Steel. ${ }^{33}$

The three opinions agree basically on the test a court should apply in considering rejection of a labor contract, ${ }^{34}$ and the House Report

26. House REPORT, supra note 2, at 17.

27. $I d$.

28. 238 F. Supp. 359 (E.D.N.Y. 1965).

29. [T] he Bankruptcy Court, when it has the power to reject a collective bargaining agreement, should do so only after thorough scrutiny, and a careful balancing of the equities on both sides, for, in relieving a debtor from its obligations under a collective bargaining agreement, it may be depriving the employees affected of their seniority, welfare and pension rights, as well as other valuable benefits which are incapable of forming the basis of a provable claim for money damages. That would leave the employees without compensation for their losses, at the same time enabling the debtor, at the expense of the employees, to consummate what may be a more favorable plan of arrangement with its other creditors.

Id. at $361-62$ (emphasis in original).

30. 519 F.2d 698 (2d Cir. 1975).

31. Id. at 707 .

32. 523 F.2d 164 (2d Cir.), cert. denied, 423 U.S. 1017 (1975) and 423 U.S. 1073 (1976).

33. The REA court remanded a district court decision permitting rejection for further findings to determine whether the labor contract was sufficiently onerous to warrant rejection, acting "substantially for the reasons stated in remanding Kevin Steel." Id. at 172.

34. The REA court proffered what would seem the most rigorous test. The court stated that rejection of a labor contract "should be authorized only where it clearly appears to be the lesser of two evils and that, unless the agreement is rejected, the [debtor] will collapse and the employees will no longer have their jobs." Id. See 28 VAND. L. REV. 1374, 1380 (1975) (approving REA's standard of allowing rejection "only when rentention of the contract would prevent [the debtor's] survival"); In re Studio Lighting, Inc., 2 BANkr. L. REP. (CCH) ff 65,929 (E.D.N.Y. Jan. 7, 1976) (petition to reject labor contract in Chap. XI denied because contract was not shown to be so burdensome as to prevent successful rehabilitation of debtor). Applied literally, the $R E A$ language would preclude judicial approval of rejection of a labor contract in Chapter IX. The municipal 
correctly observes that this test requires the debtor to make "a showing of greater burden" than in a nonlabor context. ${ }^{35}$ Yet the Report may be misleading insofar as it implies that such balancing of the equities will make rejection of municipal employee contracts extraordinarily difficult. Although worker equities may be hard to counterbalance in a Chapter XI arrangement of a private business, the outcome of the balancing test in Chapter IX will often depend on a factually distinct set of equities.

Chapter XI courts were concerned that rejection of labor contracts would deprive current employees of pension benefits and other intangible rights. ${ }^{36}$ At least as to pensions, the courts' concern seems unwarranted in Chapter IX. Admittedly losses from the rejection of a pension plan are contingent and unliquidated, since the losses will depend on the number of retirees and the pension level prevailing at the time of their retirement. For this reason claims for such losses might not be allowed and therefore would not share in the distribution of the debtor's funds under the plan in Chapter XI. ${ }^{37}$ Though contingent or unliquidated claims which have been proven

debtor can neither collapse nor be thrown into liquidation. In Chapter IX, therefore, the $R E A$ language is of questionable utility, except as suggesting a stricter test than Overseas National Airways and Kevin Steel appear to require.

The factual contexts of Kevin Steel and Overseas National Airways obscure somewhat the relative weights those panels would accord worker and debtor interests. In Kevin Steel, the debtor's prior unfair labor practices suggested that its Chapter XI petition may have been filed in bad faith as an attempt to rid itself of the union. $519 \mathrm{~F} .2 \mathrm{~d}$ at 707. In Overseas National Airways, the court found the debtor's evidence of the burdensome nature of the contract inaccurate and unconvincing. $238 \mathrm{~F}$. Supp. at 361 . Although the case clearly requires a rigorous factual demonstration of the advantages of rejection, its disapproval of the particular rejection under review did not dispute the substantive standard of oncrousness applied by the bankruptcy referee. Moreover, the discussion of rejection standards has the air of dictum: the court held that $\$ \$ 1,2,76,201-205$ of the Railway Labor Act, 45 U.S.C. $\$ \$ 151,152,156,181-185$ (1970), and $\$ 77$ of the Bankruptcy Act, 11 U.S.C. $\$ 205$ (1970), precluded any unilateral change of employment terms by the employer.

35. House RePorT, supra note 2, at 17. But see In re Klaber Bros., Inc., 173 F. Supp. 83, 85 (S.D.N.Y. 1959) (no differentiation in treatment of collective bargaining and other executory contracts); Note, Collective Bargaining and Bankruptcy, 42 S. CAL. L. REv. $477,478-81$ (1969).

36. Brotherhood of Ry. Employees v. REA Express, Inc., 523 F.2d 164, 172 (2d Cir.), cert. denied, 423 U.S. 1017 (1975) and 423 U.S. 1073 (1976); Shopmen's Local Union No. 455 v. Kevin Steel Prods., Inc., 519 F.2d 698, 707 (2d Cir. 1975). As to In re Overseas National Airways, Inc., 238 F. Supp. 359 (F..D.N.Y. 1965), see note 29 supra.

37. See the proviso to $\$ 57$ (d) of the Bankruptcy Act, Il U.S.C. $\$ 93(\mathrm{~d})$ (1970):

[A]n unliquidated or contingent claim shall not be allowed unless liquidated or the amount thereof estimated in the manner and within the time directed by the court; and such claim shall not be allowed if the court shall determine that it is not capable of liquidation or of reasonable estimation or that such liquidation or estimation would unduly delay the administration of the estate or any proceeding under this titlc.

Section $57(\mathrm{~d})$ is applicable to Chapter $\mathrm{XI}$ by virtuc of $\$ \$ 371,17$, and $63(\mathrm{~d})$, 11 U.S.C. S\$ 771, 35, 103(d) (1970). See note 38 injra. 
but not allowed are not discharged by confirmation of a Chapter XI arrangement, ${ }^{38}$ the workers' surviving claims could prove worthless if the debtor subsequently collapses and goes out of business. Workers thus might never be compensated for their losses. This inequity is less likely in Chapter IX. First, the danger that surviving claims ${ }^{39}$ will become worthless is negligible, for the debtor must continue to operate and cannot be liquidated; in that sense, a municipality, unlike a private company, cannot become judgment-proof. Moreover, almost all municipal employees participate in state or local retirement systems. ${ }^{40}$ Pension benefits due these workers for past years' completed service are generally fixed by statute, ${ }^{41}$ with employer contributions to the systems prescribed by state or municipal law."2 Rejection of collective bargaining contracts thus will usually have no effect on the accrued pension rights of municipal employees. ${ }^{43}$ (Admittedly the loss of

38. Bankruptcy Act $\$ \$ 371,17,63(d)$, 11 U.S.C. $\$ \$ 771,35,103$ (d) (1970); 9 CoLLIIR, supra note $7, \mathbb{7} 7.10[2]$, at $57 \mathrm{n} .8 ; i d$. $\{9.32[1]$, at $397-98$. Section 371 provides that the discharge of a debtor in Chapter XI excludes debts not dischargeable under $\$ 17$; the latter section in turn provides that only provable debts are dischargeable. Section 63(d) states that any contingent or unliquidated claim which has been proved under $\$ 57$ (d) but not allowed "shall not be deemed provable under this Act." Thus, contingent or unliquidated claims that are proven but unallowed are not discharged in Chapter XI.

39. In revised Chapter IX, the judge has the cxpress power to except a claim from the general discharge of the debtor's obligations. \$ 95(b)(2)(A). All other claims are discharged except those whose holders had no timely notice or knowledge of the proceedings. In Chapter IX, unlike Chapter XI, claims that are proven but unallowed are discharged unless specifically excepted by the judge. See $\$ 81(1)$.

40. See T. BleakNey, Retircient Systems for Publi EMployees 11-12 (1972); Tix Foundation, Inc., State nNd Local Empoyec Pension Systems 9-1I (1969); R. Tilove, Public EMployee Pension Fusdos 5-7 (1976).

41. E.g., N.J. St.1T. ANv. $\$ \$$ 43:16A-5 to 43:16A-7 (Supp. 1976-1977) (police and fircmen); N.Y. CirY AdMIN. CoDE $\$ \$$ B3-36.0 to B3-36.6 (1971) (New York City Employees Retirement System). Currently, municipal employee pension benefits are rarely set by collective bargaining. See R. Tilove, supra note 40, at 251 . Even where state law allows collective bargaining over pension benefits, negotiated benefit rates generally do not become effective until they are enacted into law by the legislature. Id. at 251-52.

42. E.g., N.J. Stat. AN. $\$ 43: 16-5$ (1975) (police and firemen); N.Y. City AdMin. Cone $\$ \S$ B3-17.0 to B3-19.0 (1971) (New York City Employees Retirement System).

43. In a number of states, including New lork, Florida, Illinois, and Massachusetts, municipal employee pension rights are deemed contractual rights which may not be diminished or impaired. R. TrLove, supra note 40, at 253-56. In New York, this result was achieved by constitutional amendment. N.Y. Covsr. art. $V$, $\$ 7$. Once enacted into law, these "benefit rights, whether accrued for service completed or yet to be accrued on future service, may not [so far as state law is concerned] be diminished for anyone who is already a member of the system. Less advantageous benefits may be enacted only for persons who are hired or who become members after the date of the change." $R$. Tilove, supra note 40, at 253-54.

Although the bankruptcy power permits Congress to impair contracts, subject to the constraints of due process, any intent to preempt state pension laws, at least with respect to workers whose pension benefits have vested, was specifically eschewed in the legislative debate over revised Chapter IX. 122 Covc. Rec. S4376 (daily ed. Mar. 25, 1976) (Sens. Javits and Burdick); see 122 Cong. Rec. H2381-84 (daily ed. Mar. 25, 1976) (Rep. Badillo). In addition, where benefit rights have accrued for service already completed, 
other intangible rights, such as seniority provisions, beneficial working conditions, and certain protections against lay-off remain valid equities. $)^{44}$

Equities in favor of the city in Chapter IX will be far more compelling than the equities in favor of the employer in Chapter XI. Onerous employment obligations may prevent a city from balancing its budget for some time. The prospect of an unbalanced budget may preclude judicial confirmation of the plan. ${ }^{45}$ Unless a city can reject its labor contracts, lack of funds may force cutbacks in police, fire, sanitation, and welfare services, imposing hardships on many citizens. ${ }^{40}$ In addition, because cities in the past have often seemed immune to the constraint of "profitability" faced by private businesses, their wage contracts may be relatively more onerous than those in the private sector. ${ }^{47}$

\section{B. The Consequences of Rejection}

Ordinarily, when a municipal debtor rejects an executory contract other than a collective bargaining agreement, the contractual relation-

the "contract" guaranteeing the pension payments is no longer truly executory, even by the broad definitions of the SENATE REPORT, supra note 2, and House RePORT, supra note 2 (Supplemental Views).

44. In this respect, "worker equities" in Chapter IX would be similar to those in Chapter XI. Yet Chapter XI courts may not be correct in assuming that claims for these losses cannot be estimated and allowed. Presumably, labor and management are able to appraise intangible benefits at the bargaining table. See L. REYNolds, Labor Economics AND LABor Relations 411, 423-24 (5th ed. 1970); H. Wellington, Labor and the Legal Process 32 (1968).

45. S. 2597 , supra note $2, \S 817$ (c)(7), required evidence that the city's budget would be balanced "within a reasonable time" as a precondition to confirmation. The Conference version of H.R. 10624, supra note 2, now the present Act, eliminated this cxpress requirement. Yet the CoNfERENCE REPORT, supra note 2, at 21, states that "the Senate's balanced budget requirement will be a factor that must be considered by the court as part of the court's determination that the plan is 'fair and equitable and feasible." "Accord, 122 Cong. REc. S4377 (daily ed. Mar. 25, 1976) (Sen. Hruska). Budgetbalancing is not required in Chapter $\mathrm{X}$ and XI proceedings. See House RePORT, supra note 2, at 59.60 (Supplemental Views).

46. Public interest considerations are usually less compelling in Chapters $\mathrm{X}$ and XI. If a corporate debtor is forced to curtail operations, consumers can turn to substitute products or services. Generally, no substitutes exist for the services that municipal governments provide. See $\mathrm{H}$. Wellington \& R. Winter, The Unions and the Cities $18-19,30,194-95$ (1971). When substitutes for municipal services do exist (e.g., private security protection or garbage collection), they are rarely accessible to lower income citizens.

47. See id. at 16-17, 19-20, 25-26. In determining the onerousness of a labor contract, the court would consider such factors as "Ieatherbedding" provisions which prevent the city from utilizing its manpower cfficiently, a wide disparity between wage scales contained in the contract and those prevailing in cities of similar size and cost of living, measurably lower worker productivity of municipal employees as compared with similarly paid private sector workers, and precminently, the financial ability of the city to maintain the required level of services. 
ship ends. The city elects to forego performance by the other party rather than meet the terms of the contract. Municipal labor agreements require a different calculus. The city cannot do without police, fire, and sanitation services and therefore cannot do without the employees responsible for providing them. The ongoing nature of the employment relationship will usually require renegotiation of the city's employment contracts. ${ }^{48}$

But how that renegotiation is to be conducted is less than certain; the new statute is silent on the consequences of rejection of a labor contract, and the legislative history is ambiguous. The House Report states that "renegotiation and formulation of a new contract would, of course, have to be in accordance with applicable Federal, State or municipal law." 49 The phrase "applicable Federal law" has no clear referent; the National Labor Relations Act (NLRA), which provides for collective bargaining procedures in most industries, ${ }^{50}$ is by its terms inapplicable to municipal employers. ${ }^{51}$ But many states ${ }^{52}$ and some cities $^{53}$ have passed public employee laws based substantially on the NLRA, requiring municipal employers to bargain collectively with employee representatives. According to the House Report, if state or local law mandates the observance of certain collective bargaining procedures when a contract expires, the municipal bankrupt must follow those same procedures after a contract is rejected. ${ }^{54}$

In addition, according to the House Report, state law would govern the wages and working conditions to be provided by the city during the period between rejection of the contract and conclusion of the bargaining process. Rejection would be treated as equivalent to the

48. See King, Municipal Insolvency: Chapter IX, Old and New; Chapter IX Rules, 50 AM, Bankr. L.J. 55, 62 (1976): "The obvious purpose [of rejecting a collective bargaining contract under Chapter $[X]$ is not to displace employecs but rather to renegotiate a more favorable or less burdensome agreement."

49. House RePORT, supra note 2 , at 8 .

50. The NLRA, with stated exceptions, grants employes the right to organize and bargain collectively in any industry affecting interstate commcrce. 29 U.S.C. $\$ \$ 142,157$ (1970).

51. 29 U.S.C. \$ 152(2) (Supp. IV 1974) ("The term 'employer' . . shall not include ... any State or political subdivision thercof ....") The House Report's reference to "applicable Federal law" may possibly have been to the 1974 amendments to the Fair Labor Standards Act (FLSA), recently struck down by the Supreme Court on Tenth Amendment grounds. National League of Cities v. Usery, $96 \mathrm{~S}$. Ct. 2465 (1976). Those amendments extended the FLSA's minimum wage and maximum hour provisions to most state and municipal employces.

52. E.g., Cal. Gov't Code $\$ \$ 3500-3510$ (West 1966 \& Supp. 1976); ConN. Gen. Stat. $7-467$ to $7-477$ (1975); Mass. ANN. LAws ch. 150E (Michie/Law Co-op Supp. 1975). Orel 30 states have passed statutes giving public employees the right to organize and bargain collectively with their cmployer. These statutes are indexed at LAB. L. REP. (CCH) 50,079-80 (1975).

53. E.g., N.Y. CitY Avmix. Code ch. 54 (1971 \& Supp. 1974).

54. House RIPoRr, supra note 2, at $\mathrm{S}$. 
normal "termination" of a contract.js If state law required maintenance of existing terms and conditions of employment during an interim period after expiration of a terminated contract, the same state termination provision would apply after rejection. ${ }^{56}$ Such respect for state law is said to be mandated by $\$ 83$ of the Act, which exercises constitutional caution by declaring that "[n]othing in this chapter shall be construed to limit or impair the power of any State to control, by legislation or otherwise, any municipality or any political subdivision of or in such State in the exercise of its political or governmental porvers ...."

Several members of the House Judiciary Committee issued Supplemental Views ${ }^{5 s}$ to accompany the House Report. In contrast to the majority Report, the Supplemental Views argue that the revised Chapter IX is intended to override both state termination provisions and state collective bargaining procedures. ${ }^{59}$ Where a municipality has

55. Termination is the process by which one party to a collective agreement notifies the other of its desire that the existing contract not be renewed.

56. The phrase "state termination provisions" will be used to refer to provisions of state law which bar a municipal employer's unilateral alteration of employment terms. These provisions are quite varied. Several state statutes contain termination provisions modeled on $\$ 8(d)$ of the NLRA, 29 U.S.C. $\$ 158(d)$ (Supp. IV 1974), which requires that a party desiring to terminate or modify a collective agreement give the other party 60 clays notice, offer to meet and confer, and continue the terms and conditions of the existing contract for 60 days after notice or until the contract's expiration date, whichever is later. E.g., ORE. Rev. Stat. \$ 663.165(I) (1975); Y'T. StaT. ANN. tit. 21, \$ 1621(e) (1975); W. Y. Cove \$ 21-1A-4(d) (1973). Cf. IND. Cove ANN. \$ 20-7.5-1-12(c) (Burns 1975) (school cmployees); Minn. Sr.st. AxN. \$ 179.07 (West Supp. 1976) (industries affecting public interest). Other state statutes have no express termination provisions, but makc an employer's unilateral alteration of employment terms an unfair labor practice. E.g., Colo. Rrv. Stat. \$ 8-3-108(1)(f) (1973); Hawal Rev. Stat. $\$$ 89-13(8) (Supp. 1974); Kan. StaT. $\$ 44-809(15)$ (1973); N.H. REv. StaT. ANN. $\$ 273-A: 5(1)$ (ii) (1975).

57. \$ 83. According to the Hovse REPORT, supra note 2, at 8-9, state termination provisions represent an exercise of the state's "governmental function" and therefore must be respected:

A rejection would also be sufficiently similar to a termination of such a contract so that again, applicable law, if any, would apply to the rights of the other contracting party between rejection and conclusion of the bargaining process. For example, if State or other applicable law requires maintenance of terms and conditions of employment cxisting under a terminated or rejected contract, during the interim period, that applicable law would apply under section 83 to a contract rejected under the bill. That section does not permit Chapter IX to interfere with or derogate from any State law that regulates the way in which municipalitics may execute this governmental function.

Accord, King, supra note 48 , at 62 .

58. House REPORT, supra note 2, at 57-62 (Supplemental Views).

59. Id. at 57-58. Under the supremacy clause, U.S. Const. art. VI, cl. 2, Congress can override state laws which conflict with its exercise of the bankruptcy power. E.g., International Shoe Co. v. Pinkus, 278 U.S. 261 (1929) (state law governing distribution of insolvents' property and releasing of claims superseded by Bankruptcy Act); In re Colonial Realty Inv. Co., 516 F.2d 154, 158 (1st Cir. 1975) (Bankruptcy Act overrides "idliosyncrasics of local property laws"); Elliott v. Bumb, 356 F.2d 749 (9th Cir.), cert. denied, 385 U.S. 829 (1966) (trust provisions of state law overridden); In re Hicks, $133 \mathrm{~F}$. 739 (N.D.N.X. 1905) (municipal ordinance requiring firemen to pay expenses under penalty of discharge overridden in straight bankruptcy). 
specifically requested rejection of a contract, they argue, neither the Constitution nor $\$ 83$ poses any impediment to overriding applicable state labor laws. ${ }^{60}$ The language of $\$ 83$ prohibiting interference with "political or governmental powers" appeared in the old Chapter IX ${ }^{61}$ and was retained only through "reluctance to remove tested language from existing law." "'It was not intended to restrict the court's power to permit rejection of labor contracts. ${ }^{63}$

Normally one might be inclined to disregard such minority views. But the legislative history of Chapter IX is peculiarly confused. The Senate and Conference Reports said nothing about either collective bargaining procedures or termination provisions; one would have assumed this was because they accepted the majority House Report. Yet during floor debate before the Senate vote on the Conference bill, the Senate managers suddenly manifested a different understanding, adopting in substance the position of the House minority. ${ }^{64}$ There is no in-

60. House Report, supra note 2, at 58 (Supplemental Vicws).

61. Bankruptcy Act $\S 83($ c), (i), 11 U.S.C. $\$ 403$ (c), (i) (1970).

62. House RePorT, supra note 2, at 58 (Supplemental Views). The first municipal bankruptcy legislation, Act of May 24, 1934, ch. 345,48 Stat. 800 , was declared unconstitutional in Ashton v. Cameron County Water Improvement Dist. No. 1, 298 U.S. 513 (1936), on grounds of infringing state sovereignty. Justice McReynolds, writing for the Court, objected that if Congress could extend bankruptcy legislation to political subdivisions that voluntarily requested relief, it might similarly impose involuntary proceed. ings on the states themselves. In addition, even if a state did give consent to a bankruptcy proceeding, the giving of consent violated the contracts clause, U.S. Consr. art. I, $\$ 10$, cl. 1; just as a state cannot directly impair the obligation of contracts, it "can[not] accomplish the same end by granting any permission necessary to enable Congress to do so." 298 U.S. at 531. Four years later, with the retirement of Justices Sutherland and Van DeVanter and with the beginning of the Court's new acquiescence toward economic legislation, Ashton was largely overruled by United States v. Bekins, 304 U.S. 27 (1938), upholding as constitutional the 1937 revision of Chapter IX. In distinguishing Ashton. the Bekins Court relied heavily on the Act's deference toward the exercise of governmental powers by the states, id. at 49-52, even though similar statutory language had been disregarded by the Ashton Court, see 298 U.S. at 526.

63. House REPORT, supra note 2, at $\mathbf{5 8}$ (Supplemental Views). A narrow construction of the new $\$ 83$ might be supported by the interpretation accorded its predecessor. In only one reported case since Ashton has a bankruptcy court's exercise of discretion been found to interfere with a debtor's "political or governmental powers." Spellings v. Dewey, 122 F.2d 652 (8th Cir. 1941), held that a bankruptcy court did not have jurisdiction to interfere with the election of commissioners for a drainage district, or to pass on the validity of the election after it was held. However, $\$ 83$ is also properly regarded as a safety clause inserted to prohibit any exercise of discretion which could lead to invalida. tion of the Act.

64. 122 Cong. Rec. $\$ 4377$ (daily ed. Mar. 25, 1976):

Mr. HRUSKA. But, does not the House report imply that local laws, such as those governing the negotiation and renegotiation of collective bargaining [agreements], might apply in such a case?

Mr. BURDICK. I am familiar with the language to which you refer. To use an example, it is my understanding that some States have laws which require the negotiation or renegotiation in good faith of all collective bargaining agreements and that during the period of negotiation and renegotiation the employees must remain on their jobs at the same salaries, conditions and terms. It is the intent of this legislation that any such laws should not be allowed to frustrate the purposes of 
dication that the House managers ever receded from the majority position outlined in the House Report. ${ }^{65}$

Both strands of legislative history lead to seemingly unsatisfactory results. Under the interpretation of the majority House Report, Chapter IX would preempt neither collective bargaining laws nor termination provisions. Yet application of termination provisions after rejection may impose severe hardships upon the city. Judicial approval of rejection signifies that a labor contract is financially detrimental and that the equities decidedly favor rejection. Judicial approval recognizes the city's need for immediate relief. If the city is forced to maintain the old contract terms during months of exhausting negotiations, relief is postponed indefinitely. The new contract proposals may be far less lucrative, causing the union to prolong negotiations to take advantage of the mandatory continuation of the old contract terms. The union's reluctance to reach a new agreement may seriously impede the efforts of an insolvent municipality to expedite adjustment of its debts. On the other hand, according to the Senate managers' remarks and the House Supplemental Views, the statute would override state collective bargaining laws as well as state termination provisions. This would create a confused and inequitable situation. It is not clear how long suspension of collective bargaining procedures would last, ${ }^{66}$ nor how a city would structure negotiations if a bankruptcy court, out of concern for the other creditors, objected to procedures the city might deem essential, such as binding arbitration. ${ }^{67}$ Further, the public policies underlying federal and state collective bargaining laws are fundamental; ${ }^{\text {ss }}$ the position of the Senate managers and House minority ignores these policies.

the bankruptcy procedings.

ir. BURDICK. ... [I]t is the intent of the legislation that if a State has such laws they would not apply to the petitioner negotiating or renegotiating any collective bargaining agreement during the bankruptcy proceedings.

65. What evidence can be gleaned from the House floor debate suggests the contrary. In that debate, which took place in the early afternoon, several hours before the Senate managers" apparent heresy, Representative Edwards stated: "[A]greement [in conference] was reached in a remarkably short time. The differences between the two [House and Senate] bills were technical in nature and narrow in scope." 122 CoNG. Rec. H2381 (daily ed. Mar. 25, 1976).

66. Senator Burdick stated that under the Act state labor laws "would not apply to the petitioner negotiating or renegotiating any collective bargaining agreement during the bankruptcy procecdings." 122 CoNG. REc. S4377 (daily cd. Mar. 25, 1976) (emphasis added). Even if one adopts Senator Burdick's view that suspension of state labor laws would last at least until confirmation of a plan of adjustment, there is no assurance that a new contract would have been negotiated by that time.

67. In addition, state labor laws may accord the city certain protections in the negotiating process, such as prohibition of union refusals to bargain.

68. See, e.g., NLRA $\$ 1,29$ U.S.C. $\$ 151$ (1970); N.Y. LAB. LAW $\$ 700$ (McKinney 1965); H. WeLLington, supra note $44,41-46$ (1968). 
A more workable result would be one which preserves a municipal debtor's obligation to follow applicable collective bargaining procedures in renegotiating a rejected contract, yet which absolves the city of any duty during renegotiation to maintain existing employment terms. A court construing Chapter IX might reach this result by finding that Congress had intended to preempt state termination provisions, but not state collective bargaining laws. Yet it is not easy to see from a formal perspective how a court could comfortably adopt such a potpourri interpretation of the legislative history. ${ }^{69}$ As a matter of constitutional prudence, moreover, preemption of state law should not be lightly inferred in dealing with the traditional powers of state and municipal government. ${ }^{70}$

69. Such an interpretation would require rejection of the House Report's position on state termination provisions. Yet in construing statutes, Committec reports have been "traditionally regarded as the most reliable of legislative evidence." Bishin, The Law Finders: An Essay in Statutory Interpretation, 38 S. C.IL. L. REv. 1, 14 (1965). What treatment should be accorded the Senate managers' remarks is less clear. Statements made by conferees to their respective Houses in explanation of conference agreements can be "[o]f comparable weight to committce reports," H. Hart \& A. SAcks, The Legal Process: Basic Problems in the Making and Application of Law 1267 (tent. ed. 1958). But in this instance, the fact that both the Conference Report and the House managers in reporting back were silent on the issue of precmption makes it difficult to lend much weight to the Senate managers' comments.

Even by the criterion of statutory purpose, it is hard to rationalize how a court could choose selectively from the riews of the House Report and the Senate managers. By imposing financial hardships on a municipal bankrupt, termination provisions conflict with Chapter IX's objective of restoring cities to fiscal health. Yet an argument can be made that collective bargaining enhances the union's negotiating position, leading to protracted negotiations and inflated settlements which also may forestall a city's financial recovery.

70. See National League of Cities v. Usery, 96 S. Ct. 2465 (1976), which invalidated the extension of FLSA minimum wage and maximum hour provisions to state and municipal employees on the ground that such regulation, though well within Congress's commerce power, U.S. CoNST. art. I, $\$ 8, \mathrm{cl}$. 3, invaded state sovereignty protected by the Tenth Amendment:

One undoubted attribute of state sovereignty is the States' power to determine the wages which shall be paid to those whom they employ in order to carry out their governmental functions ....

96 S. Ct. at 2471. National League of Cities does not necessarily bar all attempts to preempt state public employee legislation. The Court's opinion expressly reserved the question whether Congressional powers other than the commerce power were as severely limited by the Tenth Amendment. Id. at 2474 n.17. The Court also seemed to find, in distinguishing Fry v. United States, 421 U.S. 542 (1975), that measures which lessen wage expenses rather than increase them, and measures which are only temporarily imposed, are less objectionable than the FLSA amendments at issue in National League of Cities. $96 \mathrm{~S}$. C.t. at 2475 .

In addition, one might argue that a municipality that files for relief under Chapter IX and applies specifically for rejection of a labor contract is voluntarily seeking a benefit which Congress can properly condition on the acceptance of regulatory measures closely connected to the aid granted. See Oklahoma v. United States Civil Serv. Comm'n, 330 U.S. 127, 144 (1947) ("The offer of benefits to a state by the United States dependent upon cooperation by the state with federal plans, assumedly for the general welfare, is not unusual."); Massachusetts v. Mellon, 262 U.S. 447, 482.83 (1923). A 
Two of the Chapter XI decisions discussed above suggest an approach by which Chapter IX may be implemented workably without invoking direct preemption of state labor laws, and thus without abandoning the position of the House Report. These cases considered whether a corporate debtor wishing to reject a labor contract is subject to the termination provisions of the NLRA and Railway Labor Act (RLA). In Shopmen's Local Union No. 455 v. Kevin Steel Products, Inc., ${ }^{71}$ the Second Circuit held that a bankrupt in Chapter $\mathrm{X}$ or $\mathrm{XI}$ is not required by NLRA termination provisions to maintain the old terms and conditions of employment after rejection because such a debtor-in-possession or a trustee in bankruptcy is "not the same entity as the pre-bankruptcy company." ${ }^{2}$

A new entity is created with its own rights and duties, subject to the supervision of the bankruptcy court. ... Until the debtor here assumes the old agreement or makes a new one, it is not a "party" under section 8(d) to any labor agreement with the union and is simply not subject to the termination restrictions of the section. ${ }^{3}$

The court suggested, however, that the new entity in Kevin Steel might very well be obliged by the NLRA to bargain collectively, ${ }^{74}$ like an ordinary successor employer, ${ }^{75}$ with the representative of a majority of its employees.

In Brotherhood of Railway Employees v. REA Express, Inc., ${ }^{76}$ the Second Circuit similarly had to decide whether a bankrupt carrier, as debtor-in-possession, was covered by the RLA's requirement that a carrier adhere to the existing terms of an expired labor contract pending negotiation of a new contract. The court determined that

municipality can file for relief under Chapter IX only if it is generally authorized to do so by the state legislature, or if it has the approval of a governmental officer or agency empowered by state law to authorize particular petitions. $\S 84$. However, whether the grant of relief under an exclusive federal power such as bankruptcy can be likened to a grant of federal revenues is open to question.

71. 519 F.2d 698 (2d Cir. 1975).

72. Id. at 704 (emphasis in original).

73. Id.

74. NLRA $\$ 8(a)(5), 29$ U.S.C. $\$ 158(a)(5)$ (1970), makes it an unfair labor practice for an employer to refuse to bargain collectively. NLRA $\$ 2(1)$, (2), 29 U.S.C. $\$ 152(1)$, (2) (1970), defines "cmployer" to include corporations, trustees in bankruptcy, and receivers.

75. "It may be that the obligations of such a trustce [in Chapter $X$ or in straight bankruptcy] or debtor [in Chapter $\mathrm{X}$ or $\mathrm{XI}$ ] are analogous to those of a successor employer . . ." 519 F.2d at 704. The original successor employer case, NLRB v. Burns Security Serts., 406 U.S. 272, 277-81 (1972), held that the purchaser of a business who hires a majority of the old employees is obliged under NLRA $\$ 8(a)(5)$, 29 U.S.C. $\$ 158(\mathrm{a})(5)(1970)$, to bargain with a previous recently certified bargaining agent.

76. 523 F.2d 164 (2d Cir.), cert. denied, 423 U.S. 1017 (1975) and 423 U.S. 1073 (1976). 
the debtor was a "new employer" and therefore was "not bound to follow the elaborate and protracted procedures of [the RLA] before putting into effect its proposed terms of employment."'77 It was essential that the debtor be permitted "to act promptly, albeit unilaterally, in avoiding onerous employment terms that will prevent it from continuing as a going concern." 78 But again the debtor was obliged as a successor employer to negotiate with the old bargaining representative of its employees. ${ }^{79}$

This reasoning may permit a workable result under Chapter IX without any finding of preemption. If a state has a statute requiring collective bargaining, it seems likely that state courts will find a continuing obligation to bargain on the part of both debtors-in-possession and successor employers-as a matter of state labor policy rather than federal labor or bankruptcy law. Even without a successor employer doctrine, state labor laws covering public employees may require bankrupt municipalities in Chapter IX to bargain with the old municipal union..$^{80}$

Termination provisions are another matter. If a state follows the successor employer doctrine with respect to private businesses, it seems likely that a city in Chapter IX would escape coverage under state termination provisions within the terms of state labor law itself. For if under state law a company that has purchased the assets of another company is deemed a new employer, and therefore not obliged to continue the original contract terms, ${ }^{81}$ a debtor-in-possession would most likely be deemed a new entity as well. ${ }^{82}$ And if a private debtor-

77. Id. at 171 .

78. Id. at 170-71.

79. Id. at 170,171 .

80. Municipal employee bargaining laws generally require that "public employers" bargain collectively with employee representatives. A city in Chapter IX would remain a "public employer" as defined by thesc laws and continue under a prospective duty to bargain. See, e.g., N.Y. Civ. SERv. LAw \$201(6) (McKinney 1973).

81. It is a general rule of state law that a purchaser of assets is not liable for the contract obligations of the scller unless he cxpressly or implicitly assumes those obligations. 15 W. Fletcher, Cyclopedia of the LaW of Private Corporations $\$ 7122$ (1973). This rule applies to obligations under collective bargaining contracts. E.g., International Ass'n of Machinists v. Shawnee Indus., Inc., 224 F. Supp. 347, $351-52$ (W.D. Okla. 1963); Carouso v. Empire Case Goods Co., 271 App. Div. 149, 63 N.Y.S.2d 35 (1946), aff'd, 297 N.Y. 514, 74 N.E.2d 462 (1947); In re Swift \& Co., 76 N.Y.S.2d 881 (Sup. Ct. 1947); International Ass'n of Machinists v. Falstaff Brewing Co., 328 S.W.2d 778 (Ct. App. Tex. 1959). The rule governing liability of asset purchasers contrasts with the general rule of state law governing the liability of merged or consolidated companies. A corporation resulting from a merger or consolidation is generally liable for the contract obligations of the constituent corporations, including obligations under collective bargaining contracts. 15 W. Fletcher, supra \$ 7121; John Wiley \& Sons, Inc. v. Livingston, 376 U.S. 543 (1964); Fitzsimmons v. Western Airlines, Inc., 290 A.2d 682 (Del. Ch. 1972).

82. Like an asset purchaser, and unlike a merged company, a debtor-in-possession assumes an independent financial identity with respect to general commercial debts and obligations. It would be anomalous, as a matter of state law, to extend this independence to labor contracts in the case of asset purchasers but not debtors-in-possession. 
in-possession is deemed a "new entity" under state law, so should a city that has taken on a new identity for most financial purposes under Chapter IX.s3 By the same logic that Chapter XI courts have used to construe federal termination provisions as inapplicable to corporate bankrupts, state courts ${ }^{\mathrm{s}}$ might faithfully construe state termination provisions as inapplicable to municipal bankrupts in Chapter IX.85 State law would then present no bar to a city's unilateral alteration of employment terms after rejection. The institution of revised terms would grant the city immediate relief from onerous employment obligations. If the union were dissatisfied with the interim terms, it could exercise any right it possesses under state law to strike ${ }^{56}$

83. The analogy between a private debtor and a municipality as new entities is not so difficult as it might seem. Since Chapter XI effects no change in cquity ownership, the characterization of a private debtor-in-possession as a new entity in Kevin Steel and $R E A$ did not rely on any notion of a change in bencficial interest.

84. Because filing of a Chapter IX petition normally stays all actions against a city until the proceeding is closed, $\$ 85(\mathrm{e})(2)$, it is unlikely that state courts will often have occasion to address the applicability of state termination statutes to municipal bankrupts. Consequently, the federal court "must excrcise its independent judgment as to what the [state] statute means, guided by analogous decisions, if any, and the court's own reasoning as to the intended public policy." lA Moore's Federal Practice I 0.309(?) $(2 \mathrm{~d}$ ed. 1974). However, several states now have statutes or rules permitting certification of questions of state law to the state's highest court. See P. BAtor, P. Mishkin, D. Shapiro, \& H. Wechsler, Hart and Wechsler's The federal Courts and the federal SYSTEM 710 \& nn.2 \& 4 (1973).

85. In construing state termination provisions, a state court might consider sereral factors: (I) When the provisions were enacted, rejection of municipal employee contracts under Chapter IX was not permitted. The state legislature could not easily have anticipated that termination provisions might be applied to municipalities in bankruptcy and thus had no occasion to provide an express exception. (2) Before a municipality can seek relief under Chapter IX, the state must consent. $\$ 84$. Consent indicates the state legislature's desire that the city be financially rehabilitated in successful fashion under Chapter IX.

86. The city's unilateral alteration of employment terms undoubtedly would constitute a breach of contract under state labor law, as it does under Chapter IX. See $\$ 88$ (c). The city's breach would give the union the right to treat the contract as terminated. In the absence of state antistrike laws, there would be nothing to prevent the workers from leaving their jobs in concert. Most states, however, have passed statutes prohibiting strikes by municipal employees. E.g., ConN. GEN. STat. \$ 7-475 (1975); MICH. COMp. Laws ANN. $\$ 423.202$ (1967); N.X. Civ. SeRv. LAw $\$ 210$ (McKinney 1973); OHio REv. CODE ANN. $\$ 4117.02$ (Page 1973). If the municipality's unilateral alteration of terms prompted a strike in defiance of such statutes, the federal bankruptcy court (though not the state courts) would be powerless to stop it. Federal courts are prohibited by the Norris-La Guardia Act, 29 U.S.C. $\$ \$ 101-115$ (1970), from enjoining any "refusal to perform work or remain in any relation of employment in cases involving any labor dispute." (Section 85(e)(4) gives a Chapter IX court broad powers to enjoin any "act or proceeding" against the city. Although this language could not easily be construed to permit injunctions against strikes, the House REPORT, supra note 2, at 23, records in a burst of caution that the "breadth of this provision is not intended to overrule other, specific Federal legislation that prohibits Federal courts from issuing injunctions, such as the Norris-La Guardia Act." The House's assumption that the Norris-La Guardia Act applies to federal courts sitting in bankruptcy is most probably correct. See 6 Collier, supra note 7, if $3.09[1]$, at $479-81$ n.17.) 
and otherwise would seek to conclude a new agreement as quickly as possible, facilitating an expeditious adjustment of the city's debts. ${ }^{87}$

The apparent assumption in the House Report that state law would require a city to maintain the old contractual terms after rejection is thus ill-considered. It overlooks the possibility that state law will be interpreted by state courts harmoniously with analogous federal labor law governing employers in the private sector. The power to reject labor contracts in municipal bankruptcy is best given practical effect without implicating difficult questions of preemption.

87. When a municipality requests permission to reject a collective bargaining agreement, the court might require a statement of the revised employment terms that the city proposes to establish after rejection. The court could consider the fairness of proposed changes in light of their impact on the city, its workers, its other creditors, and the public. See Leibowitz, Municipal Bankruptcy, N.Y.L.J., June 29, 1976, at 2, col. 2. 